\section{Kidney \\ Blood Pressure Research}

\title{
The Uremic Toxin Acrolein Promotes Suicidal Erythrocyte Death
}

\author{
Mohamed Siyabeldin E. Ahmed Henning Langer Majed Abed Jakob Voelkl \\ Florian Lang
}

Department of Physiology, University of Tuebingen, Gmelinstraße 5, 72076 Tuebingen, Germany

\author{
Key Words \\ Phosphatidylserine $\bullet$ Acrolein $•$ Calcium $・$ Cell volume $・$ Eryptosis
}

\begin{abstract}
Background: Anemia is a major complication of end stage renal disease. The anemia is mainly the result of impaired formation of erythrocytes due to lack of erythropoietin and iron deficiency. Compelling evidence, however, points to the contribution of accelerated erythrocyte death, which decreases the life span of circulating erythrocytes. Erythrocytes may enter suicidal death or eryptosis, which is characterized by cell shrinkage and by cell membrane scrambling with phosphatidylserine-exposure at the erythrocyte surface. Triggers of eryptosis include increase of cytosolic $\mathrm{Ca}^{2+}$-activity $\left(\left[\mathrm{Ca}^{2+}\right]_{\mathrm{i}}\right)$. Erythrocytes could be sensitized to cytosolic $\mathrm{Ca}^{2+}$ by ceramide. In end stage renal disease, eryptosis may possibly be stimulated by uremic toxins. The present study explored, whether the uremic toxin acrolein could trigger eryptosis. Methods: Cell volume was estimated from forward scatter, phosphatidylserineexposure from annexin-V-binding, hemolysis from hemoglobin release, $\left[\mathrm{Ca}^{2+}\right]_{i}$ from Fluo3fluorescence, and ceramide from fluorescent antibodies. Results: A $48 \mathrm{~h}$ exposure to acrolein $(30-50 \mu \mathrm{M})$ did not significantly modify $\left[\mathrm{Ca}^{2+}\right]_{i}$ but significantly decreased forward scatter and increased annexin-V-binding. Acrolein further triggered slight, but significant hemolysis and increased ceramide formation in erythrocytes. Acrolein $(50 \mu \mathrm{M})$ induced annexin-V-binding was significantly blunted in the nominal absence of extracellular $\mathrm{Ca}^{2+}$. Acrolein augmented the annexin-V-binding following treatment with $\mathrm{Ca}^{2+}$ ionophore ionomycin $(1 \mu \mathrm{M})$. Conclusion: Acrolein stimulates suicidal erythrocyte death or eryptosis, an effect at least in part due to stimulation of ceramide formation with subsequent sensitisation of the erythrocytes to cytosolic $\mathrm{Ca}^{2+}$.
\end{abstract}

Copyright (C) 2013 S. Karger AG, Basel

\section{Introduction}

Chronic renal failure is complicated by severe anemia, which is at least in part explained by compromized renal erythropoietin formation and release with subsequent decrease of erythropoiesis [1-3]. Moreover, impaired formation of erythrocytes in chronic renal failure may result from iron deficiency $[4,5]$. 


\section{Kidney Blood Pressure Research}

At least in theory, the anemia of uremic patients could be worsened by accelerated death of circulating erythrocytes. Erythrocytes may undergo apoptosis-like suicidal death or eryptosis, which is characterized by cell membrane scrambling $[6,7]$. Eryptosis may be triggered by enhanced cytosolic $\mathrm{Ca}^{2+}$ concentration $\left(\left[\mathrm{Ca}^{2+}\right]_{\mathrm{i}}\right)$. The increase of $\left[\mathrm{Ca}^{2+}\right]_{\mathrm{i}}$ may be caused by $\mathrm{Ca}^{2+}$ entry through $\mathrm{Ca}^{2+}$-permeable cation channels $[7,8]$, which are activated by oxidative stress [7]. Increased $\left[\mathrm{Ca}^{2+}\right]_{\mathrm{i}}$ activates $\mathrm{Ca}^{2+}$-sensitive $\mathrm{K}^{+}$channels [7] leading to cell shrinkage due to $\mathrm{K}^{+}$exit, hyperpolarization, $\mathrm{Cl}^{-}$exit and thus cellular $\mathrm{KCl}$ and water loss [9]. Increased $\left[\mathrm{Ca}^{2+}\right]_{\mathrm{i}}$ further triggers cell membrane scrambling leading to phosphatidylserine exposure at the erythrocyte surface [7]. The $\mathrm{Ca}^{2+}$ sensitivity of cell membrane scrambling is enhanced by ceramide [7] . Eryptosis is further triggered by energy depletion [10] and activation of caspases [7, 11-14]. Eryptosis is modified by several kinases, such as AMP activated kinase AMPK [8], cGMP-dependent protein kinase [15], Janus-activated kinase JAK3 [16], casein kinase [17, 18], p38 kinase [19], as well as sorafenib [20] and sunifinib [21] sensitive kinases.

Accelerated suicidal erythrocyte death may contribute to the anemia of several clinical disorders and eryptosis may be triggered by a wide variety of xenobiotics [22-45].

The percentage of phosphatidylserine exposing erythrocytes is enhanced in chronic renal failure [46]. Little is known, however, about mechanisms stimulating eryptosis in end stage renal disease. Eryptosis is known to be stimulated by vanadate [47] and methylglyoxal [7], both substances increased in uremic plasma [7, 47]. Other uremic toxins have, to the best of our knowledge, not been tested.

The pathophysiology of anemia in renal failure has been considered to involve polyamines $[48,49]$. The polyamine degradation product acrolein is strongly involved in the harmful effects of polyamines [50]. Acrolein is a highly reactive aldehyde with cytotoxic properties [51]. Human exposure to acrolein may result from food or most importantly cigarette smoking, but acrolein can also be generated endogenously by polyamine degradation [52]. Acrolein may be generated from spermine and spermidine by amine oxidase [50, 53]. In chronic renal failure the plasma amine oxidase activity and plasma concentration of acrolein are increased, whereas the plasma concentrations of spermidine and spermine are decreased [50,53]. Cigarette smoking is particularly harmful in chronic kidney disease [54]. The present study therefore explored, whether eryptosis is triggered by the uremic toxin acrolein $[55,56]$. In the present study the effect of acrolein on $\left[\mathrm{Ca}^{2+}\right]_{\mathrm{i}}$, cell volume and phosphatidylserine abundance at the erythrocyte surface were analysed. As a result, acrolein stimulates eryptosis, the suicidal death of erythrocytes.

\section{Materials and Methods}

\section{Erythrocytes, solutions and chemicals}

Leukocyte-depleted erythrocytes were kindly provided by the blood bank of the University of Tübingen. The study is approved by the ethics committee of the University of Tübingen (184/2003V). Erythrocytes were incubated in vitro at a hematocrit of $0.4 \%$ in Ringer solution containing (in mM) $125 \mathrm{NaCl}, 5 \mathrm{KCl}, 1 \mathrm{MgSO}_{4}$, $32 \mathrm{~N}$-2-hydroxyethylpiperazine-N-2-ethanesulfonic acid (HEPES), 5 glucose, $1 \mathrm{CaCl}_{2} ; \mathrm{pH} 7.4$ at $37^{\circ} \mathrm{C}$ for $48 \mathrm{~h}$. Where indicated, erythrocytes were exposed to acrolein (Sigma-Aldrich, Steinheim, Germany) at the indicated concentrations. In $\mathrm{Ca}^{2+}$-free Ringer solution, $1 \mathrm{mM} \mathrm{CaCl}_{2}$ was substituted by $1 \mathrm{mM}$ glycol-bis(2-aminoethylether)$\mathrm{N}, \mathrm{N}, \mathrm{N}$ ',N'-tetraacetic acid (EGTA).

\section{FACS analysis of annexin-V-binding and forward scatter}

After incubation under the respective experimental condition, $50 \mu \mathrm{l}$ cell suspension was washed in Ringer solution containing $5 \mathrm{mM} \mathrm{CaCl}_{2}$ and then stained with Annexin-V-FITC (1:200 dilution; ImmunoTools, Friesoythe, Germany) in this solution at $37^{\circ} \mathrm{C}$ for $20 \mathrm{~min}$ under protection from light. In the following, the forward scatter (FSC) of the cells was determined, and annexin-V fluorescence intensity was measured in FL-1 with an excitation wavelength of $488 \mathrm{~nm}$ and an emission wavelength of $530 \mathrm{~nm}$ on a FACS Calibur (BD, Heidelberg, Germany). 


\section{Kidney \\ Blood Pressure Research}

Measurement of intracellular $\mathrm{Ca}^{2+}$

After incubation erythrocytes were washed in Ringer solution and then loaded with Fluo-3/AM (Biotium, Hayward, USA) in Ringer solution containing $5 \mathrm{mM} \mathrm{CaCl}_{2}$ and $2 \mu \mathrm{M}$ Fluo-3/AM. The cells were incubated at $37^{\circ} \mathrm{C}$ for $30 \mathrm{~min}$ and washed twice in Ringer solution containing $5 \mathrm{mM} \mathrm{CaCl}{ }_{2}$. The Fluo-3/AMloaded erythrocytes were resuspended in $200 \mu \mathrm{l}$ Ringer. Then, $\mathrm{Ca}^{2+}$-dependent fluorescence intensity was measured in fluorescence channel FL-1 in FACS analysis.

Measurement of hemolysis

For the determination of hemolysis the samples were centrifuged ( $3 \mathrm{~min}$ at $400 \mathrm{~g}$, room temperature) after incubation, and the supernatants were harvested. As a measure of hemolysis, the hemoglobin (Hb) concentration of the supernatant was determined photometrically at $405 \mathrm{~nm}$. The absorption of the supernatant of erythrocytes lysed in distilled water was defined as $100 \%$ hemolysis.

\section{Determination of ceramide formation}

For the determination of ceramide, a monoclonal antibody-based assay was used. After incubation, cells were stained for $1 \mathrm{~h}$ at $37^{\circ} \mathrm{C}$ with $1 \mu \mathrm{g} / \mathrm{ml}$ anti-ceramide antibody (clone MID 15B4, Alexis, Grünberg, Germany) in PBS containing $0.1 \%$ bovine serum albumin (BSA) at a dilution of 1:5. The samples were washed twice with PBS-BSA. Subsequently, the cells were stained for 30 minutes with polyclonal fluoresceinisothiocyanate (FITC)-conjugated goat anti-mouse IgG and IgM specific antibody (Pharmingen, Hamburg, Germany) diluted 1:50 in PBS-BSA. Unbound secondary antibody was removed by repeated washing with PBS-BSA. The samples were then analyzed by flow cytometric analysis in FL-1.

\section{Statistics}

Data are expressed as arithmetic means \pm SEM. As indicated in the figure legends, statistical analysis was made using ANOVA and $t$ test as appropriate. $\mathrm{N}$ denotes the number of different erythrocyte specimens studied. Since different erythrocyte specimens used in distinct experiments are differently susceptible to triggers of eryptosis, the same erythrocyte specimens have been used for control and experimental conditions.

\section{Results}

The present study explored the possibility that acrolein is capable to trigger eryptosis. A first series of experiments elucidated the potential effect of acrolein on cell volume. To this end, forward scatter as a measure of cell volume was determined utilizing flow cytometry of human erythrocytes. As illustrated in Fig. 1, a 48 hours exposure to acrolein was followed by a decrease of forward scatter, an effect reaching statistical significance at $30 \mu \mathrm{M}$ acrolein concentration. Accordingly, acrolein decreased erythrocyte volume.

In a second series of experiments cell membrane scrambling was analysed by determination of phosphatidylserine abundance at the cell surface. Phosphatidylserine exposing erythrocytes were identified by annexin-V-binding in FACS analysis. As illustrated in Fig. 2, a $48 \mathrm{~h}$ exposure to acrolein dose dependently increased the percentage of annexin-V-binding erythrocytes, an effect reaching statistical significance at $30 \mu \mathrm{M}$ acrolein concentration. Accordingly, acrolein exposure was followed by erythrocyte cell membrane scrambling with phosphatidylserine exposure at the cell surface. For comparison, effects of the precursors spermine and spermidine on annexin-V-binding have been tested. The administration of spermine $(0,1.5,15$ and $150 \mu \mathrm{M})$ did not significantly modify the percentage of annexin-V-binding erythrocytes $(2.18 \pm 0.36 \%, 2.49 \pm 0.32 \%, 2.31 \pm 0.49 \%$, and $1.77 \pm 0.40 \%$, respectively, $n=5)$. Moreover, the administration of spermidine $(0,1.5,15$ and $150 \mu \mathrm{M}$ ) did not significantly modify the percentage of annexin-V-binding erythrocytes $(2.78 \pm 0.42 \%, 2.30 \pm 0.41 \%, 2.31 \pm 0.44 \%$, and $2.05 \pm 0.35 \%$, respectively, $n=5)$.

Further experiments tested, whether acrolein exposure is followed by hemolysis. To this end, the percentage of hemolysed erythrocytes was quantified by determination of hemoglobin release into the supernatant. As illustrated in Fig. 2, exposure of erythrocytes 


\section{Kidney Blood Pressure Research}

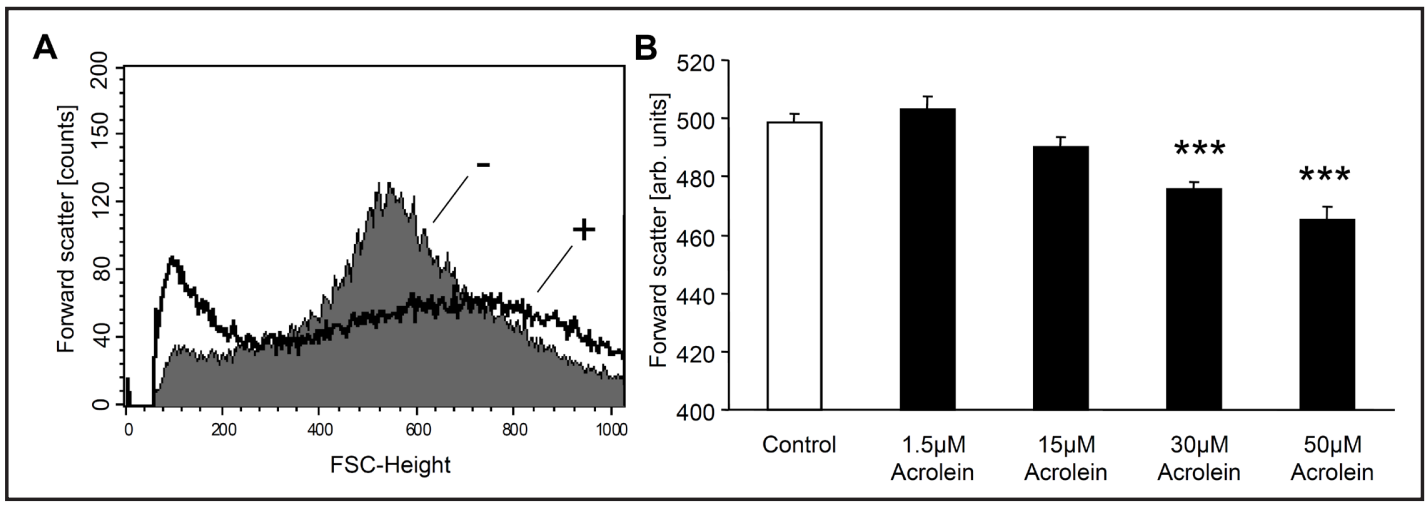

Fig. 1. Effect of acrolein on erythrocyte forward scatter. A: Original histogram of forward scatter of erythrocytes following exposure for $48 \mathrm{~h}$ to Ringer solution without (-, grey) and with $(+$, black) presence of $50 \mu \mathrm{M}$ acrolein. B: Arithmetic means \pm SEM $(\mathrm{n}=18$ - 19) of the normalized erythrocyte forward scatter (FSC) following incubation for $48 \mathrm{~h}$ to Ringer solution without (white bar) or with (black bars) acrolein (1.5 $50 \mu \mathrm{M}){ }^{* * *}(\mathrm{p}<0.001)$ indicate significant difference from the absence of acrolein (ANOVA).
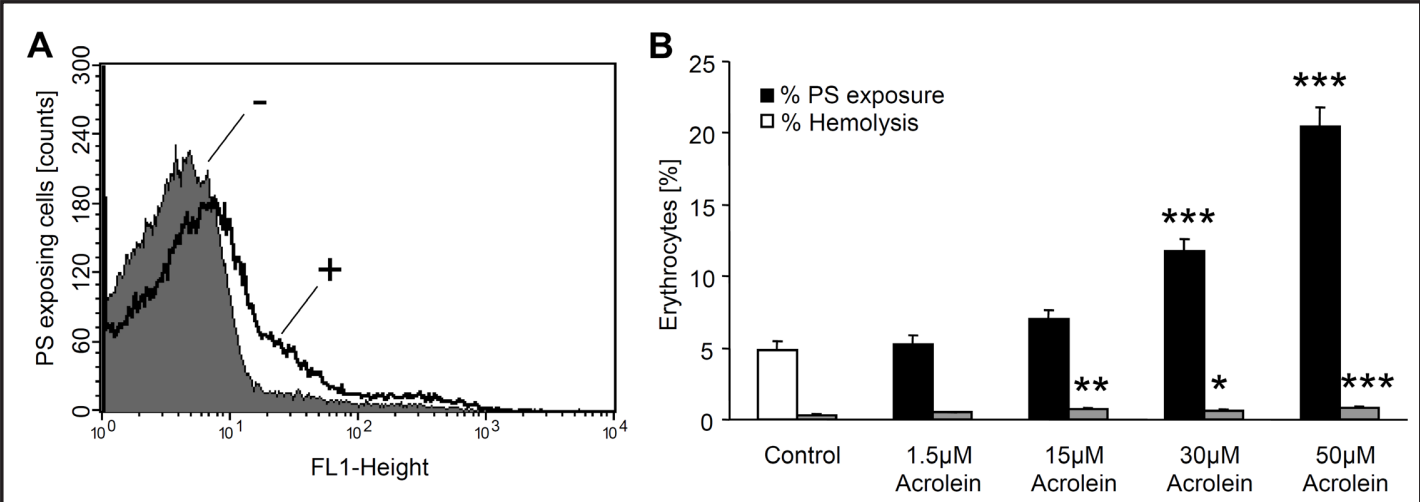

Fig. 2. Effect of acrolein on phosphatidylserine exposure and hemolysis. A: Original histogram of annexin-V-binding of erythrocytes following exposure for $48 \mathrm{~h}$ to Ringer solution without (-, grey) and with $(+$, black) presence of $50 \mu \mathrm{M}$ acrolein. B: Arithmetic means \pm SEM ( $n=18$ - 19) of erythrocyte annexin-V-binding following incubation for $48 \mathrm{~h}$ to Ringer solution without (white bar) or with (black bars) presence of acrolein $(1.5-50 \mu \mathrm{M})$. For comparison, arithmetic means \pm SEM $(n=6)$ of the percentage of hemolysis is shown as grey bars. ${ }^{* * * * * *}(\mathrm{p}<0.05,0.01,0.001$ respectively) indicates significant difference from the absence of acrolein for the respective measurements (ANOVA).

for $48 \mathrm{~h}$ to acrolein significantly increased the hemoglobin concentration in the supernatant, an effect, however, affecting only a relatively small percentage of erythrocytes (Fig. 2).

Both, cell shrinkage and cell membrane scrambling could have resulted from an increase of cytosolic $\mathrm{Ca}^{2+}$ activity $\left(\left[\mathrm{Ca}^{2+}\right]_{\mathrm{i}}\right)$. Thus, further experiments were performed to elucidate whether acrolein increases $\left[\mathrm{Ca}^{2+}\right]_{\mathrm{i}}$. To this end, erythrocytes were exposed to Ringer solution without or with added acrolein $(1.5-50 \mu \mathrm{M})$. In the following the erythrocytes were loaded with Fluo3-AM and Fluo3 fluorescence determined in FACS analysis. As illustrated in Fig. 3, following a 48 hours exposure of human erythrocytes up to $50 \mu \mathrm{M}$ acrolein remained without significant effect on Fluo3 fluorescence. Accordingly, at the concentrations tested, acrolein did not significantly increase cytosolic $\mathrm{Ca}^{2+}$ concentration.

To further elucidate the potential role of $\left[\mathrm{Ca}^{2+}\right]_{i}$, erythrocytes were exposed to $50 \mu \mathrm{M}$ acrolein for 48 hours either in the presence of extracellular $\mathrm{Ca}^{2+}(1 \mathrm{mM})$ or in the nominal absence of $\mathrm{Ca}^{2+}$ and presence of the $\mathrm{Ca}^{2+}$ chelator EGTA $(1 \mathrm{mM})$. As illustrated in Fig. 4 , the 


\section{Kidney Blood Pressure Research}

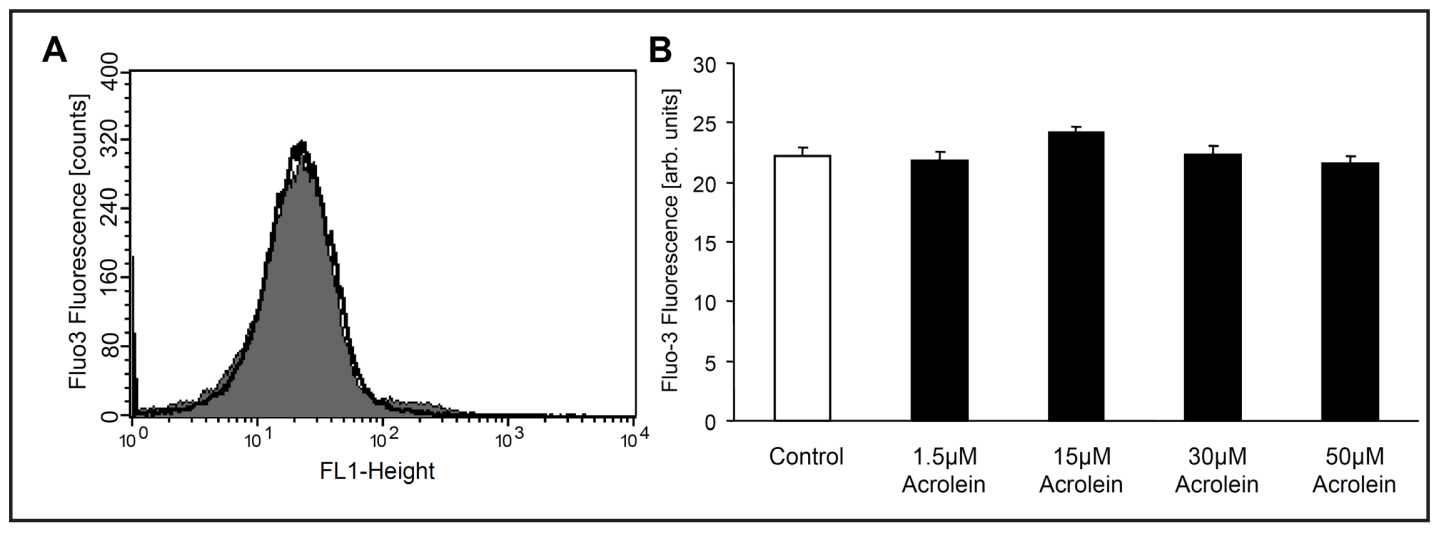

Fig. 3. Effect of acrolein on erythrocyte cytosolic $\mathrm{Ca}^{2+}$ concentration. A: Original histogram of Fluo3 fluorescence in erythrocytes following exposure for $48 \mathrm{~h}$ to Ringer solution without (grey) and with (black) presence of $50 \mu \mathrm{M}$ acrolein. B: Arithmetic means \pm SEM ( $n=18-19)$ of the Fluo3 fluorescence (arbitrary units) in erythrocytes exposed for $48 \mathrm{~h}$ to Ringer solution without (white bar) or with (black bars) acrolein $(1.5-50 \mu \mathrm{M})$.

Fig. 4. Effect of $\mathrm{Ca}^{2+}$ withdrawal on acroleininduced annexin-V-binding. Arithmetic means \pm SEM $(n=4)$ of the percentage of annexin-V-binding erythrocytes after a $48 \mathrm{~h}$ treatment with Ringer solution without (white bar) or with (black bars) $50 \mu \mathrm{M}$ acrolein in the presence (left bars, + Ca) and absence (right bars, - Ca) of calcium. ${ }^{* *}, * * *(\mathrm{p}<0.01,0.001)$ indicates significant difference from respective control (absence of acrolein) (ANOVA) \#\# $(p<0.01)$ indicates significant difference from the respective values in the presence of $\mathrm{Ca}^{2+}$.

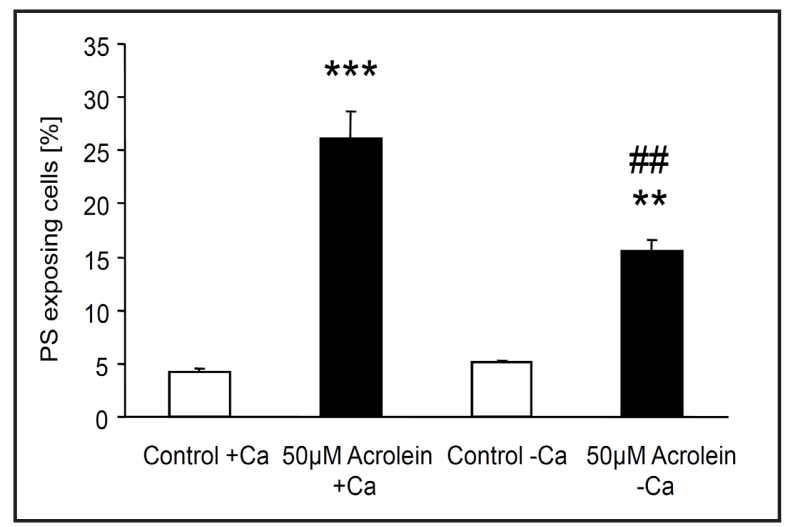

effect of acrolein on annexin-V-binding was significantly decreased in the nominal absence of extracellular $\mathrm{Ca}^{2+}$. However, even in the absence of extracellular $\mathrm{Ca}^{2+}$, acrolein still significantly increased the percentage of annexin-V-binding erythrocytes. Thus, the effect of acrolein was mainly, but not exclusively, dependent on $\mathrm{Ca}^{2+}$.

In view of the $\mathrm{Ca}^{2+}$ sensitivity of acrolein-induced eryptosis and the absence of an increase of $\left[\mathrm{Ca}^{2+}\right]_{\mathrm{i}}$ following acrolein exposure, additional experiments were performed to test whether acrolein increases the $\mathrm{Ca}^{2+}$ sensitivity of cell membrane scrambling. To this end erythrocytes were exposed to the $\mathrm{Ca}^{2+}$ ionophore ionomycin $(1 \mu \mathrm{M})$ in the absence and the presence of acrolein $(50 \mu \mathrm{M})$. As illustrated in Fig. 5, exposure of erythrocytes to the $\mathrm{Ca}^{2+}$ ionophore ionomycin $(1 \mu \mathrm{M})$ was followed by a marked increase of the percentage phosphatidylserine exposing erythrocytes, an effect significantly more pronounced in the presence than in the absence of acrolein $(50 \mu \mathrm{M})$. Accordingly, acrolein augments the cell membrane scrambling effect of cytosolic $\mathrm{Ca}^{2+}$.

As ceramide is known to enhance the sensitivity of cell membrane scrambling to cytosolic $\mathrm{Ca}^{2+}$, a further series of experiments was performed to define the effect of acrolein on formation of ceramide. Ceramide abundance at the cell surface was elucidated utilizing FITC-labeled anti-ceramide antibodies. As shown in Fig. 6, acrolein significantly increased ceramide-dependent fluorescence. 


\section{Kidney \\ Blood Pressure Research}

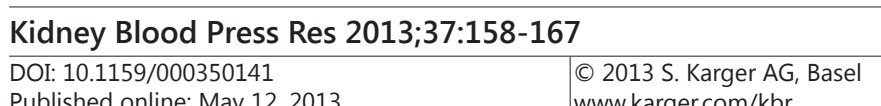

Published online: May 12, 2013

www.karger.com/kbr

Ahmed/Langer/Abed/Voelkl/Lang: Acrolein-Induced Eryptosis

Fig. 5. Effect of $\mathrm{Ca}^{2+}$ ionophore ionomycin on annexin-V-binding in absence and presence of acrolein. Arithmetic means \pm SEM $(n=5)$ of the percentage of annexin-V-binding erythrocytes after a a $48 \mathrm{~h}$ pretreatment with Ringer solution without (white bar) or with (black bars) $50 \mu \mathrm{M}$ acrolein followed by a 30 minutes treatment in the absence (left bars, -Iono) and presence (right bars, +Iono) of the $\mathrm{Ca}^{2+}$ ionophore ionomycin $(1 \mu \mathrm{M}) .{ }^{* * *}(\mathrm{p}<0.001)$ indicates significant difference from control (absence of acrolein and ionomycin) (ANOVA), \#\#\# ( $\mathrm{p}<0.001)$ indicates significant difference

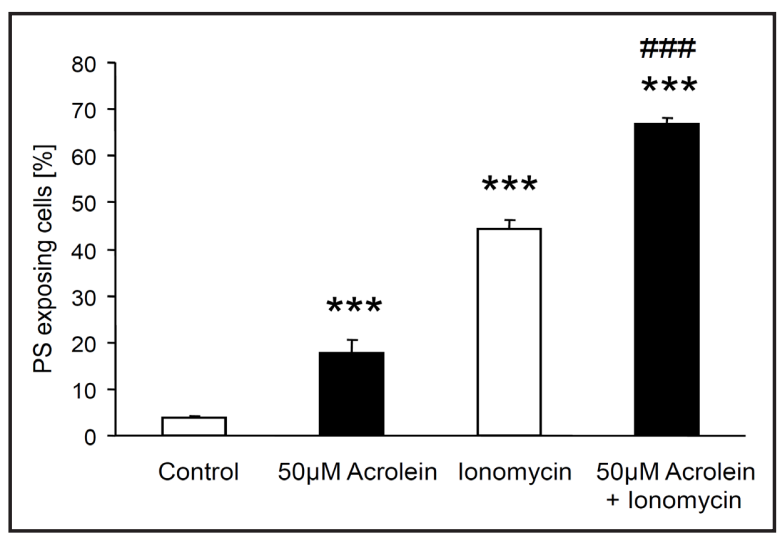
from the ionomycin treated erythrocytes in the absence of acrolein.

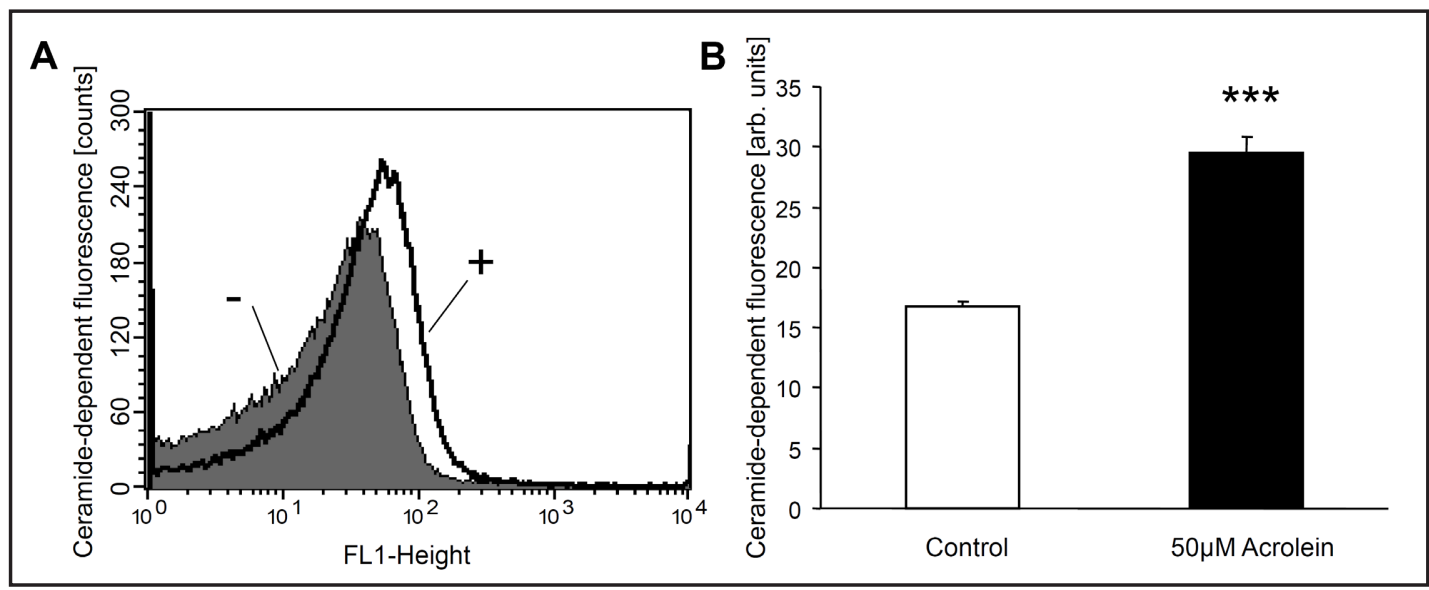

Fig. 6. Effect of acrolein on ceramide formation. A: Original histogram of anti-ceramide FITC-fluorescence in erythrocytes following exposure for $48 \mathrm{~h}$ to Ringer solution without (-, grey) and with $(+$, black) presence of $50 \mu \mathrm{M}$ acrolein. B: Arithmetic means \pm SEM $(\mathrm{n}=6)$ of ceramide abundance after a $48 \mathrm{~h}$ incubation in Ringer solution without (white bar) or with (black bars) acrolein $(50 \mu \mathrm{M}){ }^{* * *}(p<0.001)$ indicates significant difference from control (absence of acrolein) ( $t$ test).

\section{Discussion}

The present observations disclose a novel effect of acrolein, i.e. the stimulation of erythrocyte cell membrane scrambling, a typical feature of suicidal death or eryptosis. The concentrations of acrolein required for statistically significant stimulation of cell membrane scrambling $(30 \mu \mathrm{M})$ are similar to those $(25-100 \mu \mathrm{M})$ previously shown to trigger death of nucleated cells $[57,58]$.

In nucleated cells acrolein can induce both, necrotic and apoptotic cell death [52, 5759]. According to the present observations the extent of hemolysis is clearly smaller than the percentage of cell membrane scrambling suggesting that the erythrocytes die from eryptosis rather than hemolysis. Moreover, according to forward scatter, in average the erythrocytes do not swell following acrolein exposure [7, 42].

Despite the weak effect of acrolein on cytosolic Ca2+ activity, acrolein exposure leads to decrease of forward scatter reflecting a decrease of cell volume. Eryptotic erythrocyte shrinkage may result from activation of $\mathrm{Ca}^{2+}$ sensitive $\mathrm{K}^{+}$channels [7] with subsequent $\mathrm{K}^{+}$exit, cell membrane hyperpolarisation, $\mathrm{Cl}^{-}$exit and thus cellular loss of $\mathrm{KCl}$ with osmotically obliged water [9]. Whether or not those channels are activated following exposure to acrolein, remains to be shown. 


\section{Kidney Blood Pressure Research}

The acrolein induced cell membrane scrambling is similarly not the result of increased cytosolic $\mathrm{Ca}^{2+}$ activity. Nevertheless, the presence of extracellular $\mathrm{Ca}^{2+}$ is required for full stimulation of cell membrane scrambling. Accordingly, acrolein is effective by increasing the $\mathrm{Ca}^{2+}$ sensitivity of cell membrane scrambling. Along those lines, acrolein increases the scrambling effect of the $\mathrm{Ca}^{2+}$ ionophore ionomycin. As observed earlier [7], the $\mathrm{Ca}^{2+}$ sensitivity of the erythrocyte cell membrane scrambling is enhanced by ceramide. Acrolein treatment indeed resulted in an increase of ceramide formation. Thus, acrolein triggers cell membrane scrambling at least in part by increasing the formation of ceramide, which in turn increases the $\mathrm{Ca}^{2+}$ sensitivity of cell membrane scrambling. Besides its effect on erythrocyte cell membrane scrambling [7], ceramide is known to stimulate apoptosis of nucleated cells [60]. To the best of our knowledge, an effect of acrolein on ceramide formation has never been shown.

At least in theory, the stimulation of eryptosis by acrolein could contribute to the accelerated erythrocyte death in chronic renal failure. Phosphatidylserine exposing erythrocytes are rapidly cleared from circulating blood [7, 42]. In renal insufficiency, the accelerated loss of erythrocytes cannot be fully compensated by enhanced formation of new erythrocytes and anemia develops [7]. Acrolein is formed in renal failure due to increased spermine degradation by serum amine oxidase [53]. Acrolein is increased in end stage renal disease and partially removed by hemodialysis [61]. Increased acrolein levels are also observed in nephropathy models [62]. In a rat model of CKD, acrolein was lowered by an oral charcoal absorbent, a treatment associated with beneficial cardiovascular effects [63].

Acrolein is not the only substance stimulating eryptosis in renal insufficiency. Further substances reported to stimulate eryptosis and to be enhanced in renal insufficiency are vanadate [47] and methylglyoxal [7] . Along those lines, iron deficiency, which contributes to anemia in chronic renal failure $[4,5]$ is a known trigger of eryptosis [64]. It is expected that additional uremic toxins will be identified, which stimulate eryptosis and thus contribute to the anemia of patients with end stage renal disease.

Phosphatidylserine exposing erythrocytes may adhere to endothelial CXCL16/SR-PSO of the vascular wall [65] thus compromising microcirculation. Accordingly, the adhering erythrocytes may interfere with blood flow [65-70]. Moreover, phosphatidylserine exposing erythrocytes may stimulate blood clotting and thus trigger thrombosis $[66,71,72]$. The attempt to fully compensate the accelerated loss of erythrocytes by eryptosis may result in a high turnover of erythrocytes with increased numbers of phosphatidylserine exposing erythrocytes in circulating blood. Accordingly, at leastin theory, uncritical use of erythropoietin or other erythropoiesis stimulating agents [73] may jeopardize microcirculation.

\section{Conclusion}

Acrolein triggers cell membrane scrambling and cell shrinkage and thus suicidal death of human erythrocytes. The effect is at least in part due to enhanced formation of ceramide with subsequent sensitization of cell membrane scrambling to cytosolic $\mathrm{Ca}^{2+}$.

\section{Conflict of Interests}

The authors state that they have not any conflict of interests.

\section{Acknowledgements}

The authors acknowledge the meticulous preparation of the manuscript by Ali Soleimanpour. The study was supported by the Deutsche Forschungsgemeinschaft and the Open Access Publishing Fund of Tuebingen University. 


\section{Kidney \\ Blood Pressure Research}

\begin{tabular}{l|l}
\hline Kidney Blood Press Res 2013;37:158-167 \\
\hline DOI: $10.1159 / 000350141$ & $\begin{array}{l}\text { C } 2013 \text { S. Karger AG, Basel } \\
\text { www.karger.com/kbr }\end{array}$ \\
\hline Published online: May 12, 2013 &
\end{tabular}

Ahmed/Langer/Abed/Voelkl/Lang: Acrolein-Induced Eryptosis

\section{References}

1 Atkinson MA, Furth SL: Anemia in children with chronic kidney disease. Nat Rev Nephrol 2011;7:635-641.

2 Parfrey PS: Critical appraisal of randomized controlled trials of anemia correction in patients with renal failure. Curr Opin Nephrol Hypertens 2011;20:177-181.

3 Fishbane S, Nissenson AR: Anemia management in chronic kidney disease. Kidney Int Suppl 2010;117:S3S9.

4 Attanasio P, Ronco C, Anker SD, Cicoira M, von Haehling S: Role of iron deficiency and anemia in cardiorenal syndromes. Semin Nephrol 2012;32:57-62.

5 Besarab A, Coyne DW: Iron supplementation to treat anemia in patients with chronic kidney disease. Nat Rev Nephrol 2010;6:699-710.

-6 Nguyen DB, Wagner-Britz L, Maia S, Steffen P, Wagner C, Kaestner L, Bernhardt I: Regulation of phosphatidylserine exposure in red blood cells. Cell Physiol Biochem 2011;28:847-856.

7 Lang E, Qadri SM, Lang F: Killing me softly - suicidal erythrocyte death. Int J Biochem Cell Biol 2012;44:1236-1243.

-8 Foller M, Sopjani M, Koka S, Gu S, Mahmud H, Wang K, Floride E, Schleicher E, Schulz E, Munzel T, Lang F: Regulation of erythrocyte survival by AMP-activated protein kinase. FASEB J 2009;23:1072-1080.

$\checkmark 9$ Lang PA, Kaiser S, Myssina S, Wieder T, Lang F, Huber SM: Role of $\mathrm{Ca}^{2+}$-activated $\mathrm{K}^{+}$channels in human erythrocyte apoptosis. Am J Physiol Cell Physiol 2003;285:C1553-C1560.

10 Klarl BA, Lang PA, Kempe DS, Niemoeller OM, Akel A, Sobiesiak M, Eisele K, Podolski M, Huber SM, Wieder T, Lang F: Protein kinase C mediates erythrocyte "programmed cell death" following glucose depletion. Am J Physiol Cell Physiol 2006;290:C244-C253.

11 Foller M, Huber SM, Lang F: Erythrocyte programmed cell death. IUBMB Life 2008;60:661-668.

12 Foller M, Mahmud H, Gu S, Wang K, Floride E, Kucherenko Y, Luik S, Laufer S, Lang F: Participation of leukotriene C(4) in the regulation of suicidal erythrocyte death. J Physiol Pharmacol 2009;60:135-143.

13 Lau IP, Chen H, Wang J, Ong HC, Leung KC, Ho HP, Kong SK: In vitro effect of CTAB- and PEG-coated gold nanorods on the induction of eryptosis/erythroptosis in human erythrocytes. Nanotoxicology 2012;6:847856.

14 Maellaro E, Leoncini S, Moretti D, Del Bello B, Tanganelli I, De Felice C, Ciccoli L: Erythrocyte caspase-3 activation and oxidative imbalance in erythrocytes and in plasma of type 2 diabetic patients. Acta Diabetol DOI 10.1007/s00592-011-0274-0.

15 Foller M, Feil S, Ghoreschi K, Koka S, Gerling A, Thunemann M, Hofmann F, Schuler B, Vogel J, Pichler B, Kasinathan RS, Nicolay JP, Huber SM, Lang F, Feil R: Anemia and splenomegaly in cGKI-deficient mice. Proc Natl Acad Sci USA 2008;105:6771-6776.

16 Bhavsar SK, Gu S, Bobbala D, Lang F: Janus kinase 3 is expressed in erythrocytes, phosphorylated upon energy depletion and involved in the regulation of suicidal erythrocyte death. Cell Physiol Biochem 2011;27:547-556.

17 Zelenak C, Eberhard M, Jilani K, Qadri SM, Macek B, Lang F: Protein kinase CK1alpha regulates erythrocyte survival. Cell Physiol Biochem 2012;29:171-180.

18 Kucherenko YV, Huber SM, Nielsen S, Lang F: Decreased Redox-Sensitive Erythrocyte Cation Channel Activity in Aquaporin 9-Deficient Mice. J Membr Biol 2012;245:797-805.

19 Gatidis S, Zelenak C, Fajol A, Lang E, Jilani K, Michael D, Qadri SM, Lang F: p38 MAPK activation and function following osmotic shock of erythrocytes. Cell Physiol Biochem 2011;28:1279-1286.

20 Lupescu A, Shaik N, Jilani K, Zelenak C, Lang E, Pasham V, Zbidah M, Plate A, Bitzer M, Foller M, Qadri SM, Lang F: Enhanced Erythrocyte Membrane Exposure of Phosphatidylserine Following Sorafenib Treatment: An in vivo and in vitro Study. Cell Physiol Biochem 2012;30:876-888.

21 Shaik N, Lupescu A, Lang F: Sunitinib-sensitive suicidal erythrocyte death. Cell Physiol Biochem 2012;30:512-522.

22 Shaik N, Lupescu A, Lang FP: Inhibition of suicidal erythrocyte death by probucol. J Cardiovasc Pharmacol 2013;61:120-126.

23 Zelenak C, Pasham V, Jilani K, Tripodi PM, Rosaclerio L, Pathare G, Lupescu A, Faggio C, Qadri SM, Lang F: Tanshinone IIA stimulates erythrocyte phosphatidylserine exposure. Cell Physiol Biochem 2012;30:282294.

24 Shaik N, Zbidah M, Lang F: Inhibition of $\mathrm{Ca}(2+)$ entry and suicidal erythrocyte death by naringin. Cell Physiol Biochem 2012;30:678-686. 


\section{Kidney \\ Blood Pressure Research}

25 Qadri SM, Bauer J, Zelenak C, Mahmud H, Kucherenko Y, Lee SH, Ferlinz K, Lang F: Sphingosine but not sphingosine-1-phosphate stimulates suicidal erythrocyte death. Cell Physiol Biochem 2011;28:339-346.

26 Qadri SM, Kucherenko Y, Zelenak C, Jilani K, Lang E, Lang F: Dicoumarol activates $\mathrm{Ca}^{2+}$-permeable cation channels triggering erythrocyte cell membrane scrambling. Cell Physiol Biochem 2011;28:857-864.

27 Lang E, Jilani K, Zelenak C, Pasham V, Bobbala D, Qadri SM, Lang F: Stimulation of suicidal erythrocyte death by benzethonium. Cell Physiol Biochem 2011;28:347-354.

28 Lang E, Qadri SM, Jilani K, Zelenak C, Lupescu A, Schleicher E, Lang F: Carbon monoxide-sensitive apoptotic death of erythrocytes. Basic Clin Pharmacol Toxicol 2012;111:348-355.

-29 Felder KM, Hoelzle K, Ritzmann M, Kilchling T, Schiele D, Heinritzi K, Groebel K, Hoelzle LE: Hemotrophic mycoplasmas induce programmed cell death in red blood cells. Cell Physiol Biochem 2011;27:557-564.

30 Ghashghaeinia M, Toulany M, Saki M, Bobbala D, Fehrenbacher B, Rupec R, Rodemann HP, Ghoreschi K, Rocken M, Schaller M, Lang F, Wieder T: The NFкB pathway inhibitors Bay 11-7082 and parthenolide induce programmed cell death in anucleated Erythrocytes. Cell Physiol Biochem 2011;27:45-54.

31 Zbidah M, Lupescu A, Shaik N, Lang F: Gossypol-induced suicidal erythrocyte death. Toxicology 2012;302:101-105.

-32 Zbidah M, Lupescu A, Jilani K, Lang F: Stimulation of Suicidal Erythrocyte Death by Fumagillin. Basic Clin Pharmacol Toxicol 2013;112:346-351.

-33 Jilani K, Lupescu A, Zbidah M, Shaik N, Lang F: Withaferin A-stimulated $\mathrm{Ca}^{2+}$ entry, ceramide formation and suicidal death of erythrocytes. Toxicol In Vitro 2013;27:52-58.

34 Jilani K, Lupescu A, Zbidah M, Abed M, Shaik N, Lang F: Enhanced Apoptotic Death of Erythrocytes Induced by the Mycotoxin Ochratoxin A. Kidney Blood Press Res 2012;36:107-118.

35 Polak-Jonkisz D, Purzyc L: Ca Influx versus Efflux during Eryptosis in Uremic Erythrocytes. Blood Purif 2012;34:209-210.

-36 Abed M, Towhid ST, Shaik N, Lang F: Stimulation of suicidal death of erythrocytes by rifampicin. Toxicology 2012;302:123-128.

-37 Abed M, Towhid ST, Mia S, Pakladok T, Alesutan I, Borst O, Gawaz M, Gulbins E, Lang F: Sphingomyelinaseinduced adhesion of eryptotic erythrocytes to endothelial cells. Am J Physiol Cell Physiol 2012;303:C991-C999.

-38 Bottger E, Multhoff G, Kun JF, Esen M: Plasmodium falciparum-infected erythrocytes induce granzyme B by NK cells through expression of host-Hsp70. PLoS One 2012;7:e33774.

39 Gao M, Cheung KL, Lau IP, Yu WS, Fung KP, Yu B, Loo JF, Kong SK: Polyphyllin D induces apoptosis in human erythrocytes through $\mathrm{Ca}^{2+}$ rise and membrane permeabilization. Arch Toxicol 2012;86:741-752.

40 Weiss E, Cytlak UM, Rees DC, Osei A, Gibson JS: Deoxygenation-induced and $\mathrm{Ca}^{2+}$ dependent phosphatidylserine externalisation in red blood cells from normal individuals and sickle cell patients. Cell Calcium 2012;51:51-56.

41 Zappulla D: Environmental stress, erythrocyte dysfunctions, inflammation, and the metabolic syndrome: adaptations to $\mathrm{CO}_{2}$ increases? J Cardiometab Syndr 2008;3:30-34.

42 Lang F, Qadri SM: Mechanisms and significance of eryptosis, the suicidal death of erythrocytes. Blood Purif 2012;33:125-130.

43 Lupescu A, Jilani K, Zbidah M, Lang F: Induction of apoptotic erythrocyte death by rotenone. Toxicology 2012;300:132-137.

44 Lupescu A, Jilani K, Zelenak C, Zbidah M, Shaik N, Lang F: Induction of programmed erythrocyte death by gambogic acid. Cell Physiol Biochem 2012;30:428-438.

45 Kucherenko YV, Lang F: Inhibitory Effect of Furosemide on Non-Selective Voltage-Independent Cation Channels in Human Erythrocytes. Cell Physiol Biochem 2012;30:863-875.

-46 Myssina S, Huber SM, Birka C, Lang PA, Lang KS, Friedrich B, Risler T, Wieder T, Lang F: Inhibition of erythrocyte cation channels by erythropoietin. J Am Soc Nephrol 2003;14:2750-2757.

47 Foller M, Sopjani M, Mahmud H, Lang F: Vanadate-induced suicidal erythrocyte death. Kidney Blood Press Res 2008;31:87-93.

-48 Radtke HW, Rege AB, LaMarche MB, Bartos D, Bartos F, Campbell RA, Fisher JW: Identification of spermine as an inhibitor of erythropoiesis in patients with chronic renal failure. J Clin Invest 1981;67:1623-1629.

49 Kushner D, Beckman B, Nguyen L, Chen S, Della Santina C, Husserl F, Rice J, Fisher JW: Polyamines in the anemia of end-stage renal disease. Kidney Int 1991;39:725-732.

50 Sakata K, Kashiwagi K, Sharmin S, Ueda S, Igarashi K: Acrolein produced from polyamines as one of the uraemic toxins. Biochem Soc Trans 2003;31:371-374. 


\section{Kidney \\ Blood Pressure Research}

51 Tanel A, Averill-Bates DA: Inhibition of acrolein-induced apoptosis by the antioxidant N-acetylcysteine. J Pharmacol Exp Ther 2007;321:73-83.

52 Stevens JF, Maier CS: Acrolein: sources, metabolism, and biomolecular interactions relevant to human health and disease. Mol Nutr Food Res 2008;52:7-25.

-53 Sakata K, Kashiwagi K, Sharmin S, Ueda S, Irie Y, Murotani N, Igarashi K: Increase in putrescine, amine oxidase, and acrolein in plasma of renal failure patients. Biochem Biophys Res Commun 2003;305:143149.

54 Mercado C, Jaimes EA: Cigarette smoking as a risk factor for atherosclerosis and renal disease: novel pathogenic insights. Curr Hypertens Rep 2007;9:66-72.

55 Igarashi K, Ueda S, Yoshida K, Kashiwagi K: Polyamines in renal failure. Amino Acids 2006;31:477-483.

56 Thompson CA, Burcham PC: Genome-wide transcriptional responses to acrolein. Chem Res Toxicol 2008;21:2245-2256.

57 Liu-Snyder P, McNally H, Shi R, Borgens RB: Acrolein-mediated mechanisms of neuronal death. J Neurosci Res 2006;84:209-218.

58 Wang L, Sun Y, Asahi M, Otsu K: Acrolein, an environmental toxin, induces cardiomyocyte apoptosis via elevated intracellular calcium and free radicals. Cell Biochem Biophys 2011;61:131-136.

59 Tanel A, Averill-Bates DA: The aldehyde acrolein induces apoptosis via activation of the mitochondrial pathway. Biochim Biophys Acta 2005;1743:255-267.

-60 Morad SA, Cabot MC: Ceramide-orchestrated signalling in cancer cells. Nat Rev Cancer 2013;13:51-65.

61 Gugliucci A, Lunceford N, Kinugasa E, Ogata H, Schulze J, Kimura S: Acrolein inactivates paraoxonase 1: changes in free acrolein levels after hemodialysis correlate with increases in paraoxonase 1 activity in chronic renal failure patients. Clin Chim Acta 2007;384:105-112.

62 Sugiyama A, Sun J, Nishinohara M, Fujita Y, Masuda A, Ochi T, Takeuchi T: Expressions of lipid oxidation markers, N(epsilon)-hexanoyl lysine and acrolein in cisplatin-induced nephrotoxicity in rats. J Vet Med Sci 2011;73:821-826.

63 Fujii H, Nishijima F, Goto S, Sugano M, Yamato H, Kitazawa R, Kitazawa S, Fukagawa M: Oral charcoal adsorbent (AST-120) prevents progression of cardiac damage in chronic kidney disease through suppression of oxidative stress. Nephrol Dial Transplant 2009;24:2089-2095.

64 Kempe DS, Lang PA, Duranton C, Akel A, Lang KS, Huber SM, Wieder T, Lang F: Enhanced programmed cell death of iron-deficient erythrocytes. FASEB J 2006;20:368-370.

-65 Borst O, Abed M, Alesutan I, Towhid ST, Qadri SM, Foller M, Gawaz M, Lang F: Dynamic adhesion of eryptotic erythrocytes to endothelial cells via CXCL16/SR-PSOX. Am J Physiol Cell Physiol 2012;302:C644-C651.

66 Andrews DA, Low PS: Role of red blood cells in thrombosis. Curr Opin Hematol 1999;6:76-82.

67 Closse C, Dachary-Prigent J, Boisseau MR: Phosphatidylserine-related adhesion of human erythrocytes to vascular endothelium. Br J Haematol 1999;107:300-302.

-68 Gallagher PG, Chang SH, Rettig MP, Neely JE, Hillery CA, Smith BD, Low PS: Altered erythrocyte endothelial adherence and membrane phospholipid asymmetry in hereditary hydrocytosis. Blood 2003;101:46254627.

69 Pandolfi A, Di Pietro N, Sirolli V, Giardinelli A, Di Silvestre S, Amoroso L, Di Tomo P, Capani F, Consoli A, Bonomini M: Mechanisms of uremic erythrocyte-induced adhesion of human monocytes to cultured endothelial cells. J Cell Physiol 2007;213:699-709.

70 Wood BL, Gibson DF, Tait JF: Increased erythrocyte phosphatidylserine exposure in sickle cell disease: flowcytometric measurement and clinical associations. Blood 1996;88:1873-1880.

71 Chung SM, Bae ON, Lim KM, Noh JY, Lee MY, Jung YS, Chung JH: Lysophosphatidic acid induces thrombogenic activity through phosphatidylserine exposure and procoagulant microvesicle generation in human erythrocytes. Arterioscler Thromb Vasc Biol 2007;27:414-421.

72 Zwaal RF, Comfurius P, Bevers EM: Surface exposure of phosphatidylserine in pathological cells. Cell Mol Life Sci 2005;62:971-988.

73 Singh AK: What is causing the mortality in treating the anemia of chronic kidney disease: erythropoietin dose or hemoglobin level? Curr Opin Nephrol Hypertens 2010;19:420-424. 